\title{
Tural phenomenon of Monument Building in Batak Toba People Life in Pangururan District and Palipi District Samosir
}

\author{
Ulung Napitu ${ }^{1}$, Corry ${ }^{1}$, Resna Napitu ${ }^{2}$, Supsiloani ${ }^{3}$ \\ ${ }^{1}$ History Education Study Program, Faculty of Teacher Training and Education, Universitas Simalungun, \\ Indonesia \\ ${ }^{2}$ Management Study Program, Faculty of Economics, Universitas Simalungun, Indonesia \\ ${ }^{3}$ Anthropology Study Program, Universitas Negeri Medan, Indonesia \\ ulungnapitu2018@gmail.com
}

\begin{abstract}
This study aims to analyze the phenomenon of monument building culture in the life of Toba Batak tribe in Pangururan and Palipi Districts, Samosir Regency. This research uses descriptive analytic method with phenomenology approach. The phenomenological approach is a tradition of qualitative research that is rooted in philosophical and psychological, and focuses on the experience of human life (sociology). The results of this study indicate that the cultural phenomenon of monument building in the life of Toba Batak community is a form of cultural activity carried out by Toba Batak tribe as a tribute to the spirits of the ancestors or to the Ompu-Ompu, on the basis of religion and tradition that are still alive until now. This is Toba Batak tribe who highly respects the spirits of their ancestors.
\end{abstract}

Keywords phenomenon; culture; monument; Batak tribe;

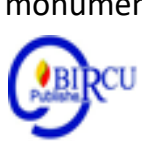

\section{Introduction}

The socio-cultural phenomenon experienced by the community is universally also found in the lives of Toba Bataks. Religious systems and socio-cultural values whose roots are the same, but in terms of their implementation are determined and influenced by the cognition, perception and social environment of each ethnic group.

Toba Batak tribe from ancient times until today still retains the traditional values inherited from their ancestors, although sometimes they are contrary to religious teachings but are still maintained. Therefore it is important that there is a process of adaptation, acculturation of socio-cultural values with religion that is adapted to today's life.

The cultural phenomenon of monument building, (Tambak $\mathrm{Na}$ Timbo) and mangongkal holi event is one of Toba Batak traditions that still survive and are maintained today in the area of origin (Bonani Pasogit) and in overseas areas (parserakan). These traditions have survived because of the strong cultural, cosmological and religious roots of Toba Bataks that affect the cognition of those who still live in their home areas and those who live in overseas areas. (Pelly, 1993: 30).

Mass monument building (tambak na timbo) in Batak community began around the 1950s when the grand tomb (grave) was inaugurated for the king / datu and considered the building to be a sacred building (Scheider, 1956: 243). A similar opinion was expressed by Sitompul (2012: 14) who said that the monument contained the names of pompadaan ompu and all the ancestors whose bones had been included in tambak na timbo (monument).

Considering the importance of the phenomenon and meaning of the monument building, mangokkal holi and panakkok saring saring in the life of Toba Batak tribe which contains the meaning of maintaining identity, and integration and is a symbol of achieving 
the cultural mission of the descendants, clans and families, this tradition cannot be separated from social life contemporary Toba Batak culture. This means that the traditional Toba Batak cultural value implies having to carry out two burials, namely primary burial (buried in the ground / tambaks) and Mangongkal holi (Secondary Funeral), namely removal of bones (panangkok saring saring). National cultural development means maintaining, preserving, protecting, spreading, utilizing and improving the quality of culture in a nation. This culture itself can be used as a source and reference in thinking of a nation to fit the norms and values that apply in the life of the nation and state. Culture is very complex, including knowledge, art, morals, law, customs, and other abilities obtained by humans as members of society (Martozet, 2019). Culture cannot be separated from religious life, which is a manifestation of ethnic theology and cosmology (Zulkifli and Ridwan, 2019).

To analyze the phenomena behind the social reality that exists in depth, comprehensively and holistically in the life of the modern Toba Batak people who have embraced religion today, as well as searching for religious roots, it is necessary to carry out research on the Phenomenon and Meaning of the Monument building in the Life of Toba Batak Tribe.

\section{Review of Literature}

\subsection{Phenomenelogy}

Nowadays phenomenology is known as a philosophical school as well as a method of thinking that studies human phenomena without questioning the causes of these phenomena, the reality of their objects and their appearance (Munir, 2008: 89). Phenomenology does not depart from the truth of phenomena as they appear as they are, but strongly believes that the phenomena that appear are objects that are full of transcendental meanings (Kuswarno, 2009: 2). Therefore, to obtain the essence of truth, it must break through and surpass visible or visible phenomena (Basrowi, 2002: 30).

The main purpose of phenomenology is to study how phenomena are experienced in mind consciousness, and in action, such as how these phenomena are valued or accepted aesthetically (Kuswarno, 2009: 2). Phenomenology seeks to understand how humans construct meaning and conceptual concepts in terms of intersubjectivity, because our understanding of the world is shaped by our relationships with others. Meaning is an important element in human life. Regarding feelings about what is wanted or not wanted, about what may and may not be done and about what is valuable and what is not valuable (P. Murroisa, 2020). Although the meaning that we create can be traced in the actions, works and activities that we do, there are still other people's roles in it (http://informationr.net./tdw/publ/paper/schutz02.html.2017).

Another definition of the phenomenology of Bretano (1874) states that phenomenology is something that occurs in the mind. Mental phenomena are conscious actions. Based on this opinion that phenomenology is something that we are aware of, objects and events around us, other people and ourselves as a reflection of our conscious experience (Kuswarno, 2009: 5). On the other hand in defining phenomenology departs from a mindset that not only looks at a phenomenon that appears, but will try to explore the meaning behind each of the symptoms (which are not visible) (Basrowi, 2002: 33). There are four conceptual components of the Hussrel phenomenon, namely:

1. Intentionality / intentional, which is an internal process in human beings associated with certain objects. This shows that to create meaning there must be cooperation between me and the world outside me. 
2. Noema and Noesis, if Noema is something that is accepted by the five human senses, or is called an objective descriptive based on how the object appears in the five senses us, then neosis is what makes us aware of the meaning when we perceive, remember, judge, feel, and think or are also called subjective descriptive.

3. Intuition is a tool to achieve ensensi by separating the ordinary from the object, to find the purity that is in it.

4. Intersubjectivity, meaning the meaning given to the object is also influenced by the empathy that we have towards others or the perceptions that we have contain our perceptions of others (Kuswarno, 2009: 40-45).

In general, discussion of philosophy always involves 4 core areas, namely:

1. Phenomenology and Ontology

Judging from ontology, phenomenology studies the nature of consciousness. Ontologically, phenomenology will be brought into the fundamental problems of the body and soul (traditional mind-body problem) for followers of Husserl, the problem of body and soul is broken down by bracketing methods, namely methods of questioning the existence of every thing around us. So phenomenology itself is separated from the ontology of the world around it. As the development of ontology discussion, Husserl's phenomena then tries to make presupposition theories about "whole and parts" (Universals and particulars), relationships and their parts and theories about ideal meanings.

\section{Phenomenology and epistemology}

With regard to epistemology whose task is to help us find knowledge, phenomenology especially changes in defining phenomena.

Phenomenology believes that it is in Phenomenon that knowledge exists. As an epistemology according to Husserl's Phenomenology, using intuition as a means to achieve truth and knowledge. Here are some of Husserl's keywords:

a) Phenomenon is an essential reality or in other words the phenomenon also includes noumena.

b) Observation is a spiritual or spiritual activity.

c) Consciousness is intentional (mentioned and directed towards the object)

d) Substance is concrete that illustrates the content and structure of reality while being affordable.

\section{Phenomenology and logic.}

As has been explained in the history of the birth of the phenomenology of logical theory about the meaning that brought Husserl to the theory of intentionality which is at the heart of phenomenology. structured can be found in languages, both everyday and in the form of symbols, such as predicate logic, mathematics and computer languages.

This brings us to the main discussion about how language shapes experiences (ideas, perceptions and emotions) and the content or meaning of these experiences. Thus there is a close relationship between phenomenology and the theory of logical language (logico linguistic theory)

\section{Phenomenology and ethics}

Phenomenology may play an important role in the field of ethics by offering an analysis of the will, judgment, happiness and attention to others (in the form of sympathy and empathy). If we examine the history of Phenomenology we will find that ethics is the ultimate goal of Phenomenology. 


\section{Research Methods}

This research uses descriptive analytic method with phenomenology approach. The phenomenological approach is a tradition of qualitative research that is rooted in philosophical and psychological, and focuses on the experience of human life (sociology). The phenomenological approach is almost similar to the hermeneutics approach which uses life experience as a tool to better understand the social cultural values or historical context in which the experience took place. The nature of qualitative research that is relevant to the phenomenological methodology that distinguishes it from ordinary qualitative research is:

- Explores the values in human experience and life.

- The focus of a research is on the whole not on the parts that make up the whole.

- The purpose of a research is to find the meaning and nature of the experience, not just to search for an explanation or to find measurements of reality.

- Obtain a description of life from a first-person perspective through formal and informal interviews.

- The data obtained is the basis for scientific knowledge to understand human behavior.

- Questions made reflect the interests, involvement and personal commitment of the researcher.

- Seeing experience and behavior as a single entity that can not be separated between subject and object or between parts of the whole (Creswell, 1998: 86).

The reason for using this research method and technique is because the problem studied concerns the phenomenon and meaning of the monument building in the life of Toba Batak tribe in Samosir Regency. Through a phenomenological approach, it is hoped that descriptions of phenomena that appear on the ground can be interpreted, their meanings and contents deeper.

The location of this research is Pangururan District and Palipi District Samosir Regency. The main informants and key informants in this study consisted of community leaders, traditional leaders, religious leaders, government leaders, traditional Batak religious leaders, scholars and members of Toba Batak tribe who settled in Samosir Regency and specifically those living in Pangururan and Palipi Districts. Primary data was collected through direct observation, conducting in-depth interviews to the informants.

\section{Discussion}

\subsection{Phenomenon of Monument Building on the Life of Toba Batak in Samosir Regency}

Community development theory advocates that the community system should allow an equality of standing for citizen roles; suggests a balanced respect for the potency of both tradition and social inventions and advocates that community system should allow an equality of standing for citizen roles in the community (Adedokun, 2019). In the monument building, simin and burial in Toba Batak community if examined from Edmund Husserl's theory of phenomenology that combines descriptive psychological with logic. The phenomenon of monument building that occurs in Toba Batak community is a phenomenon that considers as a deliberate objective charge of subjective conscious action. Based on the process of consciousness (Neosis) consisting of ideas, opinions and thoughts. Through the monument building, Simin and the burial, show their way of respecting the spirits of the ancestors is to make a more appropriate place so that the spirits of the ancestors feel more comfortable in nature. This is as expressed by Amani Pasti Simbon (Result of Simbolon) as follows:

"We built Simin to make our ancestors comfortable so that they are more comfortable in nature. So that if we do not feel disobedient to the ancestors. If we neglect our ancestors 
and do not put them in a place they deserve to live in, our lives will always be miserable and not get the blessing of our ancestors."

The monument created by the people of Samosir Regency will have an effect on creating togetherness in Batak community in Samosir. With this monument, now the people of a clan such as Sinaga, at least once a year people who have the surname Sinaga throughout the world can get to know each other and face to face at traditional events which are always celebrated once a year. Even so, some of the clans of the clan also still find it difficult to unite their clans that are spread throughout the world.

In building the monument, Batak Toba tribe cooperates with one another, especially those who have great influence both at the regional level and those who have become great officials or people in this country or abroad. Through the committees that have been formed, Toba Batak who are abroad have partly contributed funds for the monument building. Although some of them could not go home to do the monument building, but they still participated in donating money in development.

\subsection{The Clan's Monument Found in Samosir Regency}

In Toba Batak terms especially in Samosir Regency, a monument called Simin is a building made of cement and is distinguished from a tomb in general. Tambaks are referred to as higher tomb buildings where ancestral bones have been collected for generations. Whereas the Parsadaan monument is a monument building which has its own meaning with symbols attached to the monument. In addition, the monument is also considered as a warning sign or association in a clan.

With the monuments that were built, Batak Toba tribe in Samosir Regency hoped to be able to unite their developed, branched clans, and at the same time be able to know the history of their ancestors. This is as said by Edmund Husserl about neoma (actions of consciousness) and neosis: the process of awareness (ideas, opinions and thoughts) as well as semiotics: symbols, signs and constructions of meaning) that every phenomenon that occurs in society in this case Toba Batak community in Pangururan District and Palipi District have meaning behind the symbols attached to the monument. Starting from the shape of the monument, the height of the monument and everything around the monument has its own meaning. As for the monuments that have the meaning behind the monuments in Pangururan District and Palipi District, the samples in this study are as follows:

\section{a. The Monument of Sitohang's Clan}

Sitohang is one of the clans of Batak (Toba) in Samosir Regency. The Sitohang clan originates from the village of Urat in Palipi District, Samosir Regency, North Sumatra Province. The Sitohang clan belongs to the Lontung class. From Urat Samosir, the ancestors of the Sitohang clan migrated to various regions and opened a new village (lumban). Among the several destinations for the ancestors of the Sitohang clan are in the Dairi and Baringin Parbuluan in Humbang Hasundutan. From there the descendants of the Sitohang clan scattered throughout the world. In Dairi land, the descendants of the Sitohang clan even succeeded in becoming the Regent, namely Jonathan (Ompu Tording) Sitohang and KRA Johnny Sitohang Adinagoro.

The monument buiding began with the laying of the first stone on 12 August 1989. This monument was built on a piece of land measuring 50x75 meters. The land was represented by several people of Ompu Pangaribuan Sitohang ancestry. The funds collected from tok tok ripe (donations) from the descendants of the Sitohang clan around the world both from overseas children and those in Samosir itself. As explained by Joko Situmorang as follows: 
"The fund collection system for the monument building is by tok-tok ripe. Through these types of tokens, funds have begun to accumulate little by little so that they can build such a high monument. It took quite a long time for the monument building, said my father, starting from 1989 to 1991 ".

At the beginning of the Sitohang clan monument building, it spent Rp. 10,626,975. In 1989 to raise such a large fund was not easy. Rp. 10,626,975 are substantial funds if estimated at current amounts. To get that much money, all members who use the Sitohang clan work together in raising funds for the monument building process.

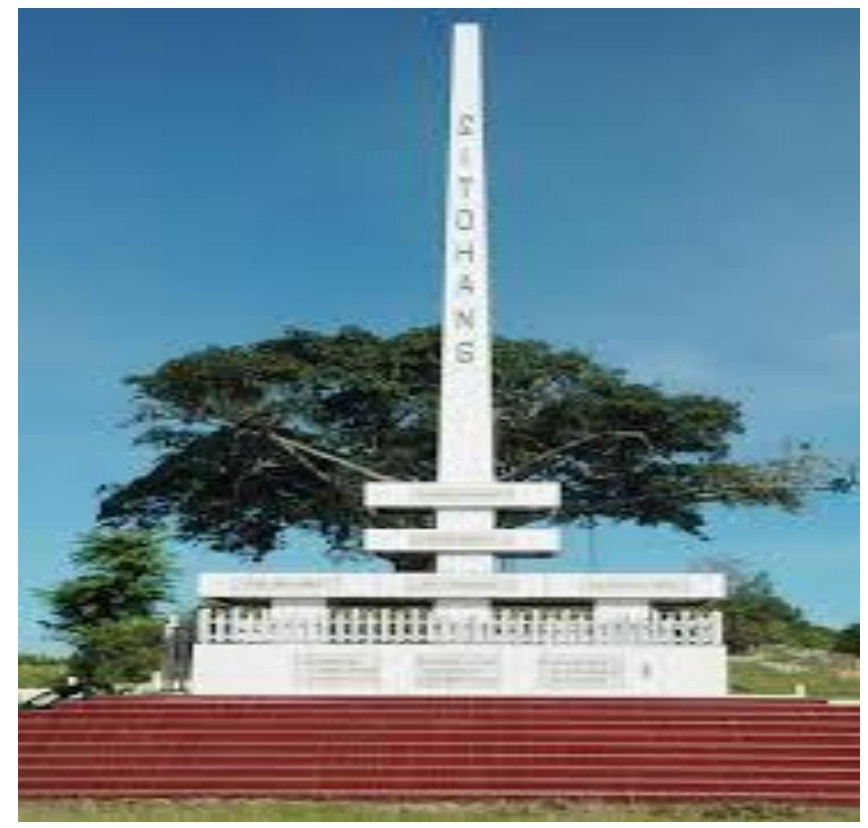

Figure 1. Monument of Sitohang's Clan

\section{b. The Monument of Toga Sinaga's Clan}

In 1964 at the initiative of several people from this pomparan who live in Medan, they tried to develop PPTSB activities by contacting Toga Sinaga figures in the city of Medan. This activity received good reception and support from all walks of life. The existence of Major Police Drs.M.H.Sinaga who was moved from Jakarta to Medan as Assistant II of KAPOLDASU welcomed the increase in PPTSB activities, who were willing to be active as members of the management.

To realize the ideas of the PPTSB activities, meeting meetings were held from Pomparan Toga Sinaga in Kotaa Medan. Based on the results of meetings held several times, as the initiator of the erection of this monument, Ama Roma Sinaga (Ompu Koko) gave an explanation of the agreement that had been obtained from the meeting, namely:

"The Toga Sinaga Monument is very important to be erected because it has a very big goal, namely as a unifying tool for all of the Toga Sinaga Pomparan that is developing on this earth. It is time for us Sinaga clan to prove itself remains one in the outside world, where we continue to use the designation of the Clan Sinaga and not Marsiolian (blood marriage). The unity in the designation of Sinaga must be maintained and preserved by establishing the Toga Sinaga Monument in our Bonapasogit ". 


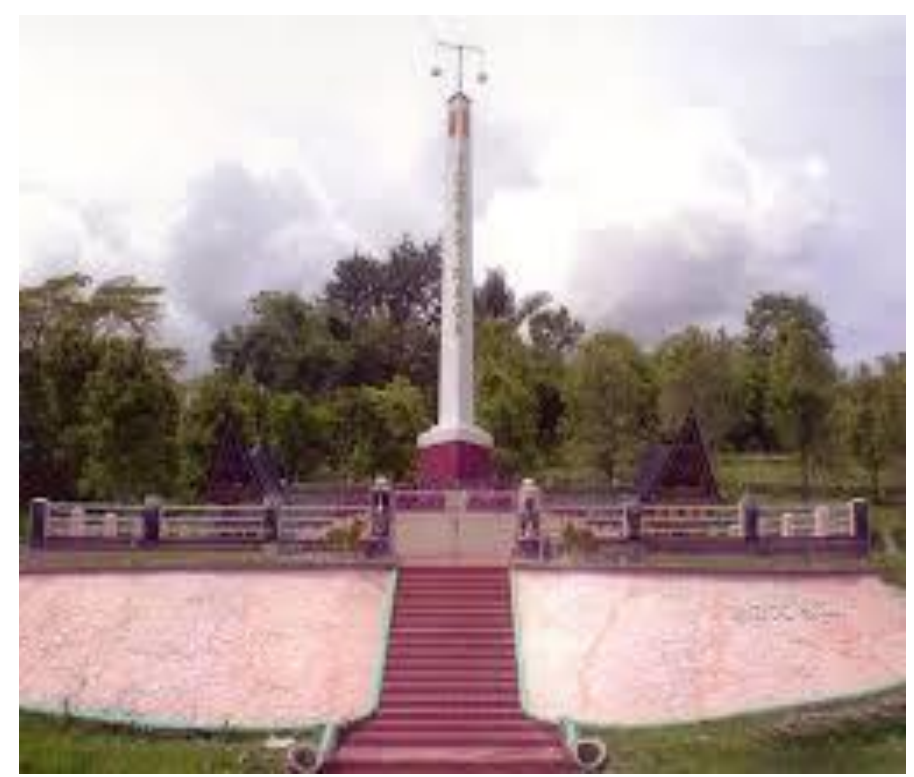

Figure 2. The Monument of Sinaga's Clan

\section{c. The Monumen of Situmorang's Clan}

To be a sign and make it easier for someone to remember by the descendants of Ompu, Mr. Situmorang, then the naming ceremony was continued with the planting of a tree named Jabi-Jabi Sisangapon. This DiJabi-Jabi Sisangapon is the Ompu of Mr. Situmorang reminded us again that the tona (message) and advice as well as the things that had been said by Ompu Mr. Situmorang to be carried out by his pomparan.

Jabi- Jabi Sisangapon can be seen today in the area of the location of Oтри Mr. Situmorang monument in Urat Village, Palipi District, Samosir Regency, North Sumatra. To perpetuate the name of Отри Mr. Situmorang on 5-7 July 1990, the Отри Mr. Situmorang monument was built and inaugurated in Urat, Palipi District, Samosir Regency, North Sumatra. As explained by Nelsson Situmorang (Отри Samuel Situmorang) as follows:

"In 1990, to mark the territory of Ompu Mr. Situmorang, under a banyan tree or Jabijabi, a Tombstone was erected with the name of the Jabi-jabi Sisangapan and about 20 M2 from Sisangapan's Jabi-jabi, a monument or Oтри Mr. Situmorang monument was built for three days and night ${ }^{\wedge}$

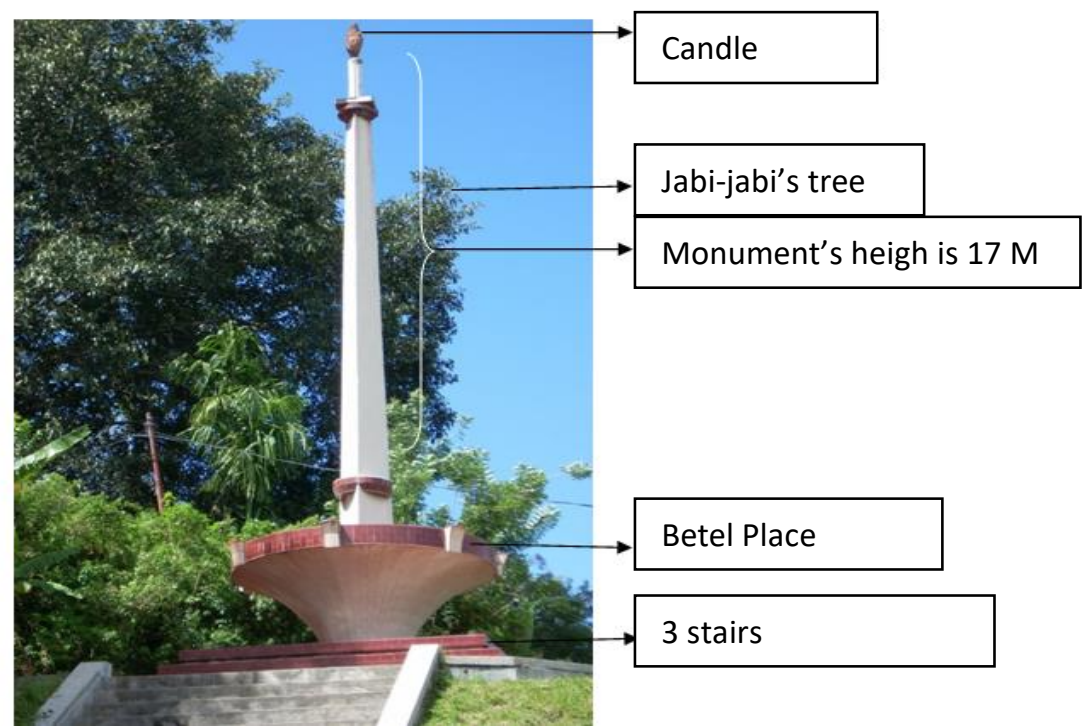

Figure 3. The Monument of Situmorang's Clan 


\section{d. The Monument of Pandiangan's Clan}

Toga Pandiangan is the third child of Raja Lottung, the Toga Pandiangan monument is located in Urat, Palipi District, Samosir Regency, North Sumatra. From the list and sequence of the tarombo above it can be seen that Samosir Pakpahan, Gultom, Harianja, Sitinjak are part of the Pandiangan clan. And they should have used the Pandiangan clan as their identity (Pandiangan Samosir, Pandiangan Gultom, etc.), but some of them did not include pandiangan in front of their clan.

Tandi Pandiangan Monument is one form of unity and unity of the descendants of the Pandiangan toga clan. Pandiangan Toga has two children namely Toga Batu (Batuara, Parhusip) and Toga Sihombar (Rumahombar, Pinaungan, Lumban Siantar, Hutabalian) Lumbantungkup, Lumbanraja. And in 2005 the Pandiangan parsadaan toga monument was restored for the second time in seven days and seven nights.

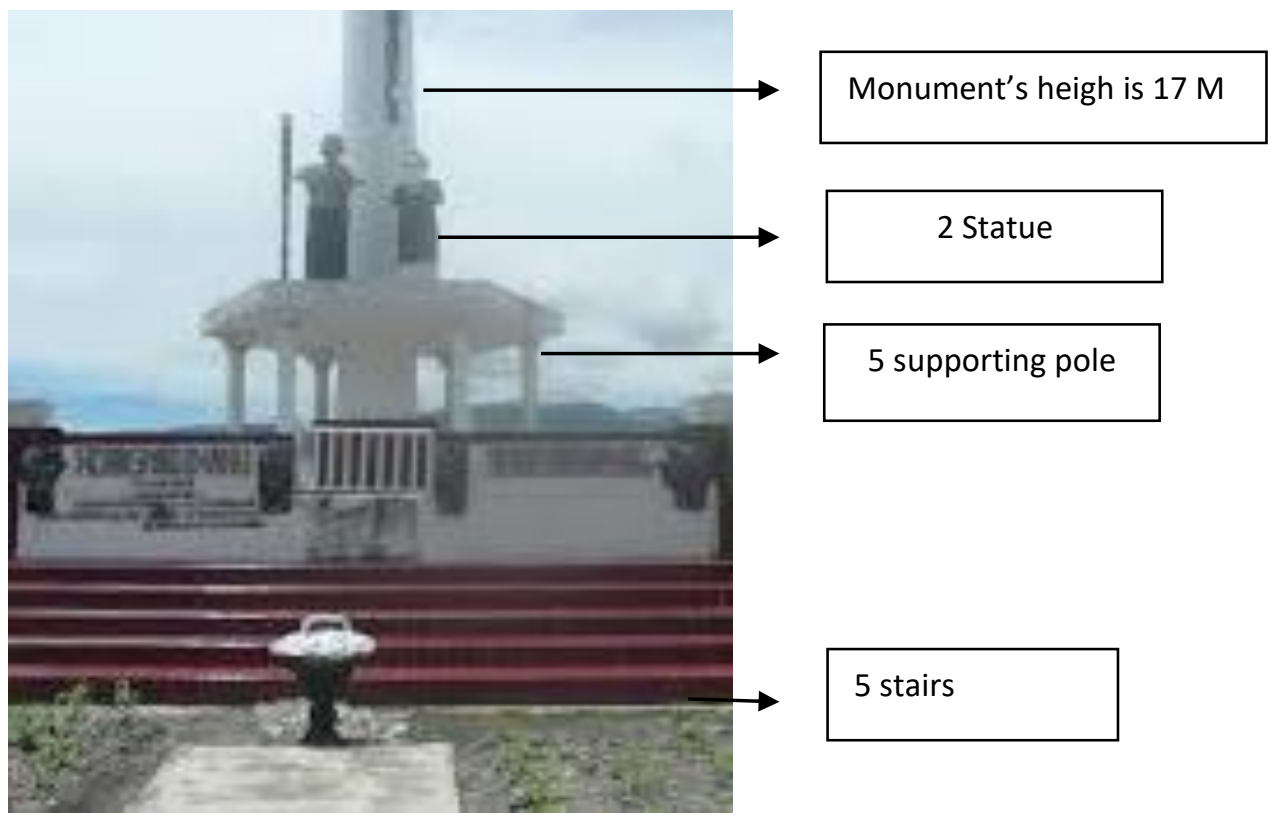

Figure 4. Pandiangan Monument

\section{e. Clan Manik’ Clans}

Manik is one of the clans of Toba Batak tribe in Pangururan District, Samosir Regency. Manik beads come from 5 ancestors, including the following: (a) Manik clan descendants of Si Inum Aek Sasunge, the second child of King Saruksuk. This clan originally settled in the area of Tanjung Kasau, East Sumatra, (b) Manik Clan descended from Silau Raja, (c) Manik Clan branch from Sigalingging family of Munthe Tua. This Manik Clan is related to Banuarea and Tendang children from Ompu Bada, (d) Manik Clan descended from Gajah Manik. This lake is a Naibaho family that originally settled in Dairi precisely around the Lake Si Cike-cike area. This Manik is related to the Ujung, Lift, Bintang, Kudadiri, Sinamo, and Capa (sapa) and (e) Manik clans. The fifth Clan is the Pardabuan lineage, Si Godang Ulu's first child or often referred to as Sihotang who resides in Dairi. Liberty Manik, the author of the song Satu Nusa Satu Bangsa, is one of the Manik Clan of this branch. 


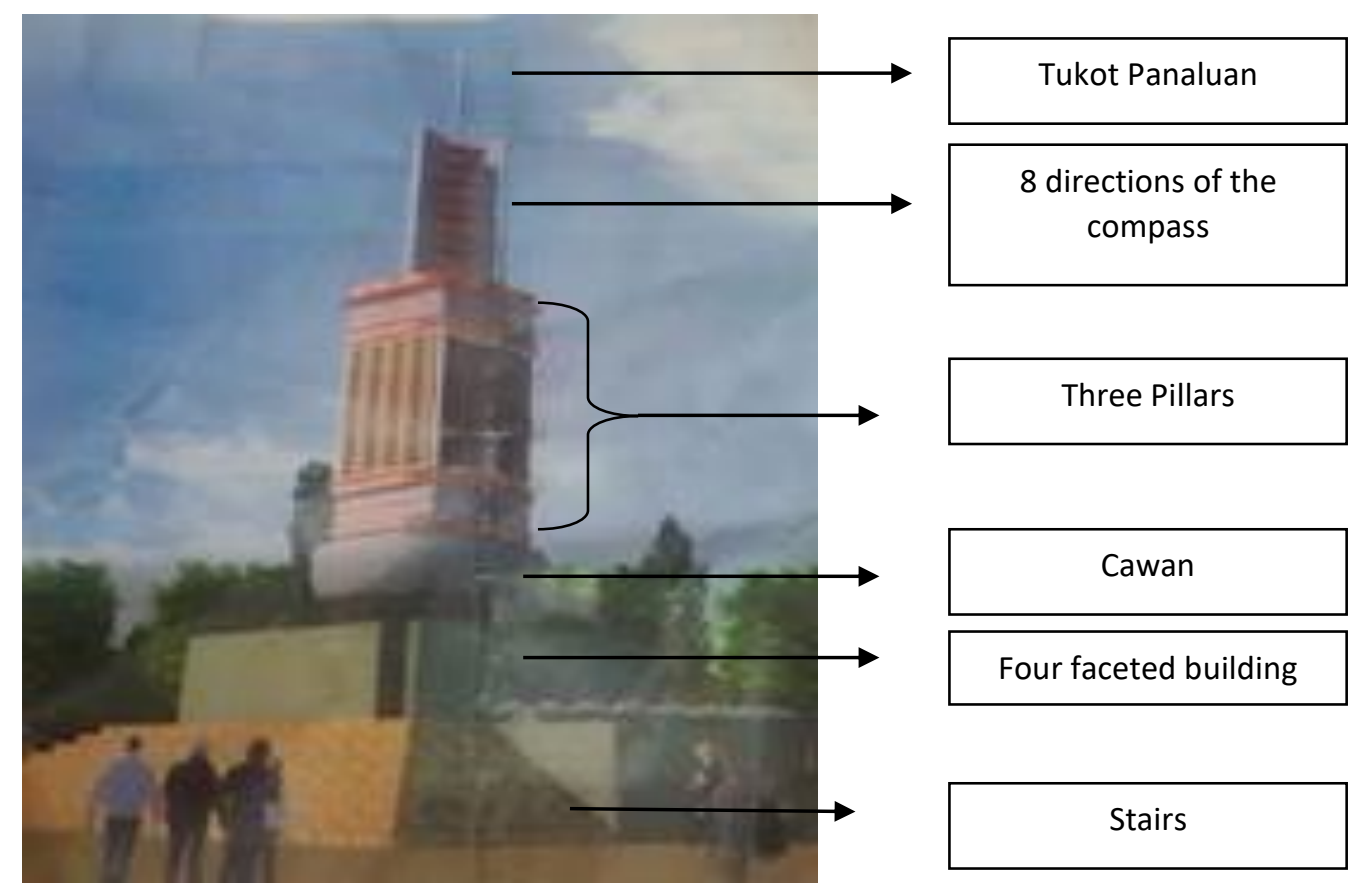

Figure 5. The monument of Manik Raja

\section{f. Siringo-Ringo Clan Monument}

The Siringo-Ringo clan came from Sipitu Ama, which consisted of Situmorang Pande, Suhut Ni Huta, Lumban Nahor, Siringo ringo, Sitohang Dolok, Tonga and Sitohang Toruan. Rumapea is a smart person, smart and very famous for his intelligence. The fact is that Rumapea is a descendant of King Situmorang, 4 siblings of which Rumapea is included, to this day there are only 3 siblings left.

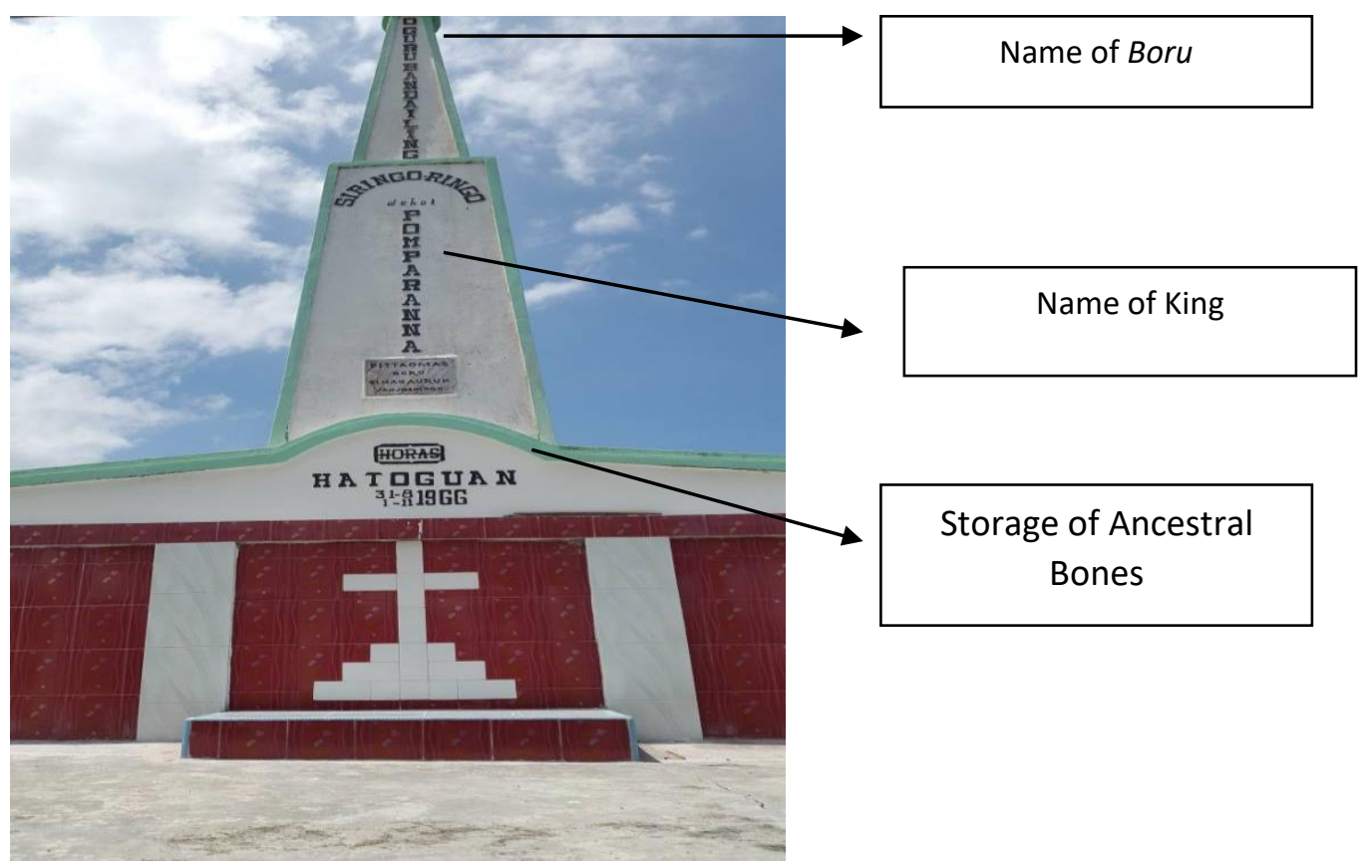

Figure 6. Siringo-Ringo Monument 


\subsection{The Cultural Phenomenon of Monument Building in the Perspective of Religion}

The monument was built in various forms and models, in building a clan monument, the funds used to build the monument came from donations of all clan descendants or members of their respective families. As explained by Mardin Siregar (Ompu Samuel Siregar) as follows:

"The model and shape of the monument that was built was based on mutual agreement with. If all have agreed with the agreed forms and models, a committee and budgeting of funds needed for the monument building will be formed. Likewise, by building a private grave or having a nuclear family, all must be discussed first".

The monument building received wide support from Toba Batak people, both those who were in Bona Parsogit (their hometown), as well as those who were overseas (parserah). Support was also provided by many Christian church leaders. The inauguration of the monument and the tomb is done with a traditional Batak Toba ceremony in the form of a small scale (a party for three days and three nights) or on a larger scale of seven days and seven nights. In general, the Christian Batak people assess there is nothing wrong with the rise of the erection of various magnificent monuments and graves.

From the perspective of each religion that is believed by each person or Toba Batak community, especially the people of Samosir Regency in two Districts, namely Pangururan District and Palipi District, it can be seen that there are differing views between one belief (religion) with another religion regarding the monument the monument. The different views can be noted in the following explanation:

\section{a. Lutheran Christianity}

In the Lutheran Christian community, they consider that the construction of the clan monument carried out by Toba Batak community, especially in Samosir Regency, has significance for their descendants and ancestors in the grave. As explained by Hasiholan Simbolon (Bapak Pasti Simbolon) as follows:

"In the Lutheran Christian community it certainly has a thousand meanings behind the monuments that have been formed that are almost hundreds of years old or newly built at this time. The monuments not only contain meaning that depicts the family tree in Toba Batak community, especially Samosir, but also illustrates that from the ancestors of our ancestors we also feel proud to take up repeated bones and give high respect to the ancestral spirits or spirits of our ancestors. They feel proud there and can be more respected by ancestors from other clans."

\section{b. Non-Lutheran Christianity}

In the context of today's Christian society, it is not possible for Batak people to go back to worshiping the spirits of the ancestors in the same way as before. This method is sure to be strongly opposed by the church. The construction of monuments is a new way by Batak people in expressing the beliefs of hasipelebeguon that have not been eroded by the church from the hearts of Batak people. This shows that the spirits of the ancestors (devil angels) keep on trying so that the Christian Batak people continue to pay their respects and worship. The devil gave new ideas to the people who were influential to create a new form of worship to him.

\section{c. Catholic Religion}

The construction of a monument in Batak Toba community in Samosir district is seen from the perspective of the Catholic religion that the Catholic community also highly respects and respects the spirits of their ancestors or ancestors. The Catholic Church itself has 
translated intercessory prayers for the dead contained in their Mass liturgies into tribal languages. However, the Catholic idea of the symbolic meaning of the sacrifice of Christ, which is why they requested that their relatives who had died also be saved because of the victim, was rejected in the HKBP's admission.

At present, the HKBP tries to accommodate adat by incorporating Christian values into traditional ceremonies carried out by Batak community, especially the HKBP congregation itself. To avoid the hypocritical life seen in traditional parties, such as the monument, pilgrimage and others who practice pagan life by asking for blessings from ancestral spirits, the church now facilitates these traditional events. One way the church is to open the gondang.

\section{d. Islam}

The construction of a monument to a Muslim community is something that is permissible. But that does not mean that Muslim communities make offerings to the spirits of their ancestors. In the corner of Islamic religion, some Toba Batak people carry out the construction of a monument which is a form of unity and unity among clans within a certain clan. So even though different beliefs or religions in Toba Batak community do not become an obstacle or obstacle to unifying the clan.

As revealed by Muhammad Taufik Efendi Sinaga (Ompu Ilham Sinaga) as follows:

"There are some Toba Batak people who are Muslim like me, in my opinion, there is no problem in building clan monuments. Because it is a form of unity and unity of Toba Batak community. Like us, the people with the surname Sinaga. We have built a monument with megak in the village of Urat, Palipi sub-district. There was also built a mosque for a place of worship for Muslims. When there are events held by the organizing committee every year, we go there to join the party event.

\subsection{The Cultural Phenomenon of Monument Building (Tambak Natimbo) in Samosir} Regency in terms of the Intellectual Group Perspective and Community Leaders

The Samosir community sees the positive impact of the erection of the monument, which is to strengthen relationships between generations. This is something done to get to know some offspring. Strong confidence in the belief in ancestors, where there is still a relationship between people who live with people who have died, so that respect and communication are needed for people who have died.

The establishment of this monument is also growing due to the economy of a family that has been said to be established plus the success of a family. the amount they respect their ancestors. The establishment of this monument is done to know one another among several descendants, or to know the identity of a family. As explained by Poltak Hutauruk (Ama) as follows:

"The independence of the monument is a sign of respect to the ancestors which was built to commemorate the services and as a tribute to our ancestors. Respect for the ancestors is in accordance with Samosir's philosophy, Habonaron do Bona. namanggoluh atap matei pe dosdo bani Tuhan, which means the living and dying equal to God. That is why according to us we must pay homage to our ancestors by erecting a pillar which is someone who can live the Fifth Law". Another thing was conveyed by Faris Manik, based on the results of the interview stating:

"The establishment of this monument is done as a form of our respect for the fighters. With the aim that the next generation knows and rewards the foregoing warriors so that it becomes a reflection of him in watering and watering". 


\subsection{The Cultural Phenomenon of Monument Building (Tambak Natimbo) in Samosir}

Regency in terms of the Perspective of the Lay Community

The opinion of Toba Batak people in Samosir that the spirits of the dead are still alive somewhere and will provide health if he is worshiped by his family. No wonder the zendeling during the evangelization period received sharp criticism. For the zendeling the relationship between people who are still alive and dead no longer exists. God never recommended that people live to worship the spirits of the dead, but only to God alone. Because God is part of the living and the dead.

Tobati Batak tribe did not accept that the corpse affected by tactics was buried near the village or public cemetery, because there was an understanding that his spirit would disrupt people's lives. That is why people affected by tactics will be buried far from villages because they are seen as not good people. Therefore there are graves of people who are considered good and there are graves of people who are considered evil. In the burial service is seen as part of the church's task that cannot be underestimated.

In the next development, a problem arose around the burial regarding the habit of mangongkal holi (moving bones) from the old place to the new place that was built at no small cost. Until now, the ritual of worshiping spirits still has not completely disappeared, although in a different form. In tribal religion, parents and tondong (wife and brother) are seen as bearers of blessings, so when they die their spirits are still considered to be present to give blessings.

In Batak tribal beliefs, the spirit of the deceased will inhabit a place called huta parsadaan parpudi. Because the place was so far away on earth, the family left behind and the relatives of the deceased were asked to provide provisions for the spirit's journey. In celebration of burial ceremonies, especially for elderly parents (saur matua), a lively party is held, especially since the family is classified as a wealthy family or nobles.

\section{Conclusion}

Pangururan District and Palipi District, Samosir Regency that the phenomenon of monument building in the life of Toba Batak community is a form of cultural activity carried out by Toba Batak tribe as a tribute to the spirits of the ancestors or to Ompu-Ompu, on the basis of religion and tradition that still life up to this time in Toba Batak tribe highly respects the spirits of their ancestors.

The monument is one place that will unite a clan and clan groups. The monument in Toba Batak community in Samosir is called the Pesadaan Monument where with the monument, a clan group will more often make offerings to its ancestors. In addition, with the existence of the monument, it is expected that fellow clans will meet and silaturrahmi relations will be maintained between clan relatives. In this study there were six monuments discussed as samples, namely the Sitohang's clan, Sinaga's clan, Situmorang's clan, Toga Pandiangan's clan, Manik Raja's Clan and Siringo-Ringo's Clan which were found in Pangururan District and in Palipi District.

\section{References}

Aditjontro, GJ. 2004. Kisah Daud melawan Goliath Di Pedalaman Tanah Batak. Medan : Bakungsu.

Agger, Ben. 2013. Teori Sosial Kritis, Jakarta :KreasiWacana.

Alvin, Y. SO dan Swarsono, 1991. Perubahan Sosial dan Pembangunan di Indonesia, Jakarta : LP3ES. 
Anonim. 2014. Alkitab (holy bible). Jakarta: Lembaga Alkitab Indonesia.

Barthes, Roland. 1972. Membedah Mitos-Mitos Budaya Massa. Jakarta: Jalasutra

Bartlett, H H, 1928. "The Sacred Edifices of The Batak of Sumatera", Michigan in Academy. pp. 209-304.

Basrowi dan Sukidin. 2002. Metode Penelitian Kualitatif dalam Perspektif Mikro. Surabaya. Insan Cendekia.

Castles, Lance. 2001. Kehidupan Politik Suatu Kepresidenan di Sumatera: Tapanuli 19151940. Jakarta: Gramedia.

Chekki, A. 1973. "Modernization and Kin Network in a Developing Society", in Journal Sociologus 3, pp. 151-161.

Danim, Sudarwan. 2002. Menjadi Peneliti Kualitatif. Jakarta: Pustaka Setia.

Dede, Mulyanto, 2014. Pemikiran Antropologi . Jakarta: Marjin Kiri.

Dhavamony, M. 1995. Fenomenologi Agama. Yogyakarta Kanisuis

Dinas Pariwisata, 2013. Jejak Peradaban Bangsa Batak (Batak Trait di Pusuk Buhit Samosir). Pangaruruan.

Durkheim, E. 1964. The Division of Labour In Society, (terjemahan George Simpson), New York : The Free Press.

Evans - Pritarchad, E. E, 1986. Antropologi Sosial (alih bahasa : Nancy Simanjuntak), Surabaya : BumiAksara

Furchan. Arief, 1992. Metode Penelitian Kualitatif, Surabaya : Usaha Nasional

Garna, Judistira K. 1992. Teori-Teori Perubahan Sosial, Bandung : PPS - UNPAD

Hutagalung.WM. 1991. Pustaha Batak. Medan: Tulus Jaya.

Husrell Edmund. 1970. The Crisis Of European Sciences and Transendental Phenomenology. Evanstone: L North Western University Press.

Ihromi, T. O, 1987. Pokok - Pokok Antropologi Budaya, Jakarta :Gramedia.

Kartini, 1983. "Asosiasi Klan Orang Batak Toba di Jakarta”. Dalam Prisma No. 1 Tahun XII. Jakarta: LP3ES.

Merton, R. L. 1986. Sosial Theory and Social Structural (terjemahan bambowolaiya) Yogyakarta : UGM - Press.

Miles dan Huberman, 1992. Analisa dan Data Kualitatif (terjemahan Rohidi, TR). Jakarta : UI - Press.

Pedersen, Paul B. 1975. Darah Batak dan Jiwa Protestan. Jakarta : BPK Gunung Mulia.

Peirce, Charles, Sanders. 1982. "The Theory of Signs in Robert E. Innis". (ed.) Semiotic, An Introductory Anthology. Bloomington: Indiana University Press.

Pelly, U. 1989. Integrasi Antara Suku Bangsa Dalam Masyarakat Majemuk. Jakarta : Depdikbud.

Saragih, Djaren, 1980. Hukum Perkawinan Adat Batak, Bandung :Tarsito.

Schreiner, Lother. 1996. Adat dan Injil : Perjumpaan Adat dengan Kristen di Tanah Batak.. Jakarta : BPK Gunung Mulia.

Weber, Max, 2007. Etika Protestan dan Semangat Kapitalisme, Yogyakarta : Jejak.

Wiradyana, Ketut dkk. 2014. Sumatera Utara Catatan Sejarah dan Arkeologi. Medan: Kamsius.

W. Marsden., 1975. The History of Sumatera. Kuala Lumpur.Oxford University Press.

Zaprulkhan, 2015. Filsafat Ilmu Sebuah Analisis Kontemporer. Jakarta, Rajawali Press.

Zenkins, Rechard. 2008. Identitas Sosial. Jakarta: Bina Media.

Zulkifli and Ridwan, Muhammad. 2019. Revitalization of the traditional values lost due to the commodification of art/crafts: a case study of Bataknese traditional Ulos. Asian Ethnicity, 541-554 